ISSN 0258-7122 (Print), 2408-8293 (Online)

Bangladesh J. Agril. Res. 44(3): 453-467, September 2019

\title{
EFFECT OF ETHEPHON ON RIPENING AND POSTHARVEST QUALITY OF MANGO
}

\author{
A. A. SABUZ ${ }^{1}$, M. G. F. CHOWDHURY ${ }^{2}$, M. M. MOLLA ${ }^{3}$ \\ M. H. H. KHAN ${ }^{4}$ AND M. MIARUDDIN ${ }^{5}$
}

\begin{abstract}
The experiment was conducted at the laboratory of Postharvest Technology Division, BARI to evaluate the effect of postharvest application of 6 concentrations $(0,250,500,750,1000 \& 10000 \mathrm{ppm})$ of ethephon on ripening and postharvest qualityof mango (cv. Langra) fruits harvested at mature green stage on $3^{\text {rd }}$ week of June in 2011 and 2012. The treated fruits were assessed for physiological changes such as ripening $\%$, weight loss $(\%)$, biochemical aspects such as TSS ( ${ }^{0}$ Brix), titratable acidity (\%), reducing sugar (\%), total sugar $(\%)$, ascorbic acid content $(\mathrm{mg} / 100 \mathrm{~g})$, total carotenoids $(\mu \mathrm{g} / 100 \mathrm{~g})$, carbon di oxide production ( $\mathrm{ml} / \mathrm{g}$ fruit) and residual level of the applied ethephon during storage period. The observations were recorded at 2 days interval during 6 days storage at ambient condition $\left(23 \pm 2{ }^{\circ} \mathrm{C}\right.$ with $\left.80 \pm 5 \% \mathrm{RH}\right)$. Complete yellow color (full ripe) was developed on the fruits treated with 500-1000 ppm ethephon at 4 days of storage while yellowish green and greenish yellow color was developed on $250 \mathrm{ppm}$ treated and control fruits, respectively, and $10000 \mathrm{ppm}$ ethephon treated fruits overripened at this period. At 6 days of storage, 250 ppm ethephon treated fruits got ripen and 500-1000 ppm ethephon treated fruits overripened whereas $10000 \mathrm{ppm}$ treated fruits got rotten and control one was still unripe. Irrespective of ethephon treatments, weight loss of fruits, TSS, reducing sugar, total sugar, carbon di oxide production and total carotenoid showed increasing trends upto 6 days whereas titratable acidity, ascorbic acid and residue level of ethephon showed decreasing trends in both years. At 4 days of storage, 750-1000 ppm ethephon dipped fruits induced uniform attractive yellow color while untreated control fruits remained yellowish greenish (unripe) even after 6 days of storage. At 6 days of storage TSS, reducing sugar, toatal sugar, ascorbic acid and total carotenoid content were found maximum in 750-1000 ppm treated fruits compared to $250-500 \mathrm{ppm}$ treated fruits. The residue level of ethephon in mango fruits treated with ethephon concentrations $(250-1000 \mathrm{ppm})$ at 6 days of storage was found below 2 ppm $(0.11 \mathrm{ppm}-0.54 \mathrm{ppm})$, which is safe for human consumption. Therefore, mangoes ripened by using ethephon@7501000 ppm can be consumed safely without any health risk.
\end{abstract}

Keywords: Mango, Ethephon, Ripening, Residue, postharvest quality.

\footnotetext{
1,2,3,4\&5 Postharvest Technology Division, Bangladesh Agricultural Research Institute (BARI), Gazipur, Bangladesh.
} 


\section{Introduction}

Mango (Mangiferaindica L.) belonging to the family Anacardiaceae is one of the most important commercially grown fruits in Bangladesh. It is known as 'aam' considered as the king of fruits due to its excellent flavor, taste, nutritive value, processing qualities and its delicacy for the table (Doke et. al., 2018). But, it is highly perishable in nature. Bangladesh occupies $8^{\text {th }}$ position among mango growing countries and produces about $2.74 \%$ of world's total mango production. In Bangladesh, the total production of mango fruits is about 12.88 lakh metric tons from 0.42 lachectors of land in 2016-2017 (BBS, 2018). It is major fruit crop cultivated in tropical and subtropical zones of the world. In Bangladesh it grows well in north-western and south-western region. But recently it is cultivated in all parts of the country. It is an abundant source of carotene, precursor of "vitamin A" after ripening.

Ripening is a process in fruits that causes them to become more palatable. In general, a fruit becomes sweeter, less green and softer as it ripens. The process of fruit ripening is chiefly regulated by a gaseous plant hormone called ethylene. The chemical commonly used to ripen fruits commercially is ethephon (2chloroethyl phosphonic acid) which penetrates into fruit and decomposes to ethylene(Alexander and Grierson, 2002). Aqueous solution of ethephon is stable below $\mathrm{pH}$ 3.5. Above $\mathrm{pH} 3.5$, the hydrolysis of ethephon begins with the release of free ethylene along with chloride and phosphate ions (Sukhjit, 2017).

In natural condition, mango fruits harvested at mature but unripe condition ripen slowly leading to high weight loss, desiccation and ripening is also uneven. Transporting and distributing mango fruits from farmer's field to consumer's basket can take several days. During this time ripen fruits become overripe and inedible. A part of naturally ripened fruits can also be damaged during transportation causing great loss to farmer. For this reason farmers harvest their fruits at mature green stage and apply ethephon to ripen artificially minimizing postharvest loss. Early and uniform ripening and color development can be achieved by dipping of mango fruits (physiologically mature but unripe) in diluted ethephon solution which is recommended for a number of climacteric fruits including mango (Bhandariet. al., 2017; Doke et. al., 2018; Gurjar et al., 2017; Sukhjit, 2017 ), banana (Mahajan et. al., 2010), tomato (Moniruzzaman et. al., 2015), guava (Mahajan et. al., 2008), and pear (Dhillion and Mahajan, 2011) and their recommended dosage of ethephon is 500-1000 ppm. When the the mature fruits dipped in aqueous solution of ethephon, ethephon enters into the fruit cells, releases ethylene and hastens the ripening process(Zhu et al., 2005).

Farmers use ethylene releasing chemicalsm namely Tomtom, Harvest, Promot, Ripen, Prolong, Ethrel, Goldplus, etc. in high doses (10000 ppm or more) on 
mangoes to quicken the ripening process and to increase the shelf life (Anon., 2014). Hakim et. al. (2012) opined that ripening chemicals are considered hazardous to human health and they have to be used within safe recommended level. Recently there have been a mixed opinions on the toxicity of ethephon among the consumers all over the country. Ethephon has been registered with EPA (US Environmental Protection Agency) since 1973 as a plant growth regulator used to promote fruit ripening and flower induction. It is a chemical which is irritant to the skin or the eyes but it is not skin sensitizer and carcinogen as classified by IARC(International Agency for Research on Cancer) as group D (not carcinogenic to human) and FAO pointed out maximum allowable daily intake for ethephon at $0.05 \mathrm{ppm}(\mathrm{mg} / \mathrm{kg}$ ) body weight/day (Bui, 2017). Recommended maximum residue level of ethephon is $2 \mathrm{ppm}(\mathrm{mg} / \mathrm{kg})$ of treated fruit (Anon., 2001). Optimum dose for ripening of mango fruits has yet not been developed in our country. The present study was therefore, conducted to determine the optimum concentrations of ethephon for ripening of mango without affecting its nutritional and postharvest qualityduring storage at ambient temperature.

\section{Materials and Methods}

Site: The present investigation was carried out at the Laboratory of the Postharvest Technology Division in Bangladesh Agricultural Research Institute during $3^{\text {rd }}$ week of June of the year 2011-12 maintaining temperature $23 \pm 2^{0} \mathrm{C}$ and $\mathrm{RH} 85 \pm 5 \%$. Fruits were carried from the farmer's field to the laboratory in plastic crates covering themselves in newspaper.

Plant material: The mango (cv.Langra) which were physiologically mature and have attained the full size, light green with tinge of yellow at apical end were collected from farmers field nearby Volahat Upazilla, Chapai-nawabganj to use for the study. Fruits were harvested on $18^{\text {th }}$ June, 2011 and $20^{\text {th }}$ June, 2012. The fruits were selected on the basis of uniformity, maturity and size (200-250 gm). The experiment was laid out in Completely Randomized Design (CRD) with 6 treatments with3 replications for each treatments.Selected fruits were divided into two parts. One for investigating chemical parameters at 2 days interval upto 6 days and other one was kept in plastic box at ambient condition to examine physical parameters at same interval upto 6 days of storage.

Treatment setting: The experiment consisted 6 level of ethephon concentrations $\left(\mathrm{T}_{1}=\right.$ control, $\mathrm{T}_{2}=250 \mathrm{ppm}, \mathrm{T}_{3}=500 \mathrm{ppm}, \mathrm{T}_{4}=750 \mathrm{ppm}, \mathrm{T}_{5}=1000 \mathrm{ppm}$ and $\mathrm{T}_{6}=$ $10000 \mathrm{ppm}) \cdot \mathrm{T}_{6}(10000 \mathrm{ppm})$ is being used by the farmers as common ripening practice. Prior to use, fruits were washed with clean water, dipped for 2 minutes in $250 \mathrm{ppm}$ "propiconazole" and dried with air flow before setting the experiment. Then the fruits were dipped for 5 minutes in the following 
concentrations of ethephon solution as stated above.The temperature was set at $23 \pm 2^{\circ} \mathrm{C}$ and $\mathrm{RH} 85 \pm 5 \%$.

After that, the fruits were kept at ambient temperature for 10 minutes in an attempt to reduce possible chemical injury and being dried up. The control fruits were dipped for 5 minutes in tap water without using the ethephon solution. The number of fruits treated under each treatment was 12 . The source of ethephon was Ripen-15 as it was available at the market.

Parameters studied: The parameters studied were percentage of ripening, physiological weight loss (\%), titratable acidity (\%), total soluble solid(TSS), reducing sugar $(\%)$, total sugar $(\%)$, ascorbic acid content $(\mathrm{mg} / 100 \mathrm{~g})$, total carotenoid $(\mu \mathrm{g} / 100 \mathrm{~g})$ and carbon di oxide production $(\mathrm{ml} / \mathrm{g}$ fruit $)$. Each data were recorded at 2 days interval upto 6 days.

Percentage of ripening: In order to determine the ripening percentage, mango fruits were daily observed for their color development and when skin color turned to full yellow, they were considered as ripe. Ripening percentage was calculated following the formula;

Ripening $(\%)=\frac{\text { Number of ripe fruits }}{\text { Totalnumber of fruits }} \times 100$

Weight loss: Weight loss was calculated by following formula;

Weight loss of fruits $(\%)=\frac{\text { Initialweight }- \text { Final weight }}{\text { Initialweight }} \times 100$

Ascorbic acid content: For ascorbic acid measurement, 10g pulp was homogenized in $50 \mathrm{~mL}$ of $3 \%$ cold metaphosphoric acid $\left(\mathrm{HPO}_{3}\right)$ using a blender for $2 \mathrm{~min}$ and filtered through Whatman filter paper No. 2. The clear supernatant was collected for assaying ascorbic acid by 2, 6-dichlorophenolindophenol titration following the method of Ranganna (1986). Ten milliliters of aliquot were titrated with $0.1 \% 2$, 6dichlorophenolindophenol solution until the filtrate changed to pink color persisted for at least 15 seconds and the titration volume of 2, 6-dichlorophenolindophenol was recorded. Prior to titration 2, 6-dichlorophenolindophenol solution was calibrated by ascorbic acid standard solution. Ascorbic acid content was calculated according to the titration volume of 2, 6-dichlorophenolindophenol and results were expressed as $\mathrm{mg} / 100 \mathrm{~g}$ fresh weight.

Ascorbic acid content (mg/100g) $\frac{\text { T x D x V1 x } 100}{\text { V2 x W }}$

Where $\mathrm{T}=$ Titre, $\mathrm{D}=$ Dye factor, $\mathrm{V} 1=$ Volume made up, $\mathrm{V} 2=$ Volume of extract taken for estimation, $\mathrm{W}=$ Weight of sample taken for estimation. 
Titratable acidity of mango pulp: It was determined following the method described by Ranganna (1986).

The titratable acidity (TA) was analyzed using the titration method. Pulp sample $(10 \mathrm{~g})$ were homogenised using a kitchen blender with $40 \mathrm{ml}$ of distilled water. The mixture was then filtered through cotton wool. The filtrate $(5 \mathrm{ml})$ with one to two drops of phenolphthalein $(0.1 \%)$ as indicator was titrated using $0.1 \mathrm{~N} \mathrm{NaOH}$ to an endpoint pink ( $\mathrm{pH}$ 8.1). The results were expressed as the percentage citric acid per $100 \mathrm{~g}$ fresh weight.

Total titratable acidity $(\%) \frac{\mathrm{T} \times \mathrm{N} \times \mathrm{E} \times \mathrm{V} 1 \times 100}{\mathrm{~V} 2 \times \mathrm{W}}$

Where $\mathrm{T}=$ Titre, $\mathrm{N}=$ Normality of $\mathrm{NaOH}, \mathrm{V} 1=$ Volume made up, $\mathrm{E}=$ Equivalent weight of malic acid, V2= Volume of extract taken for estimation, $\mathrm{W}=$ Weight of sample taken for estimation.

TSS content of mango pulp:Total soluble solid (TSS) in the extracted juice of fruits was measured by a Digital Hand Refractometer (ATAGO (Brix $=0$ to 32) by placing a drop of pulp solution on its prism and direct reading was recorded and the results were expressed as ${ }^{0}$ Brix.

Total sugar \& reducing sugar (\%) measurement:Total sugar and reducing sugar content of fruit was estimated by the following procedures described by Lane and Eynon (1923).

Standardization of Fehling's solution

50 milliliter of both Fehling's solution A and Fehling's solution B were mixed together in a beaker. Ten milliliter of mixed solution was pipetted into a $250 \mathrm{ml}$ conical flask and $25 \mathrm{ml}$ distilled water was added to it. Standard sugar solution was taken in a burette. The conical flask containing mixed solution was heated on a hot plate. When the solution began to boil, 3 drops of methylene blue indicator solution were added to it without removing the flask from the hot plate. Mixed solution was titrated by solution. The end point was indicated by de-colorization of the indicator.

Fehling's solution was calculated by using the following formula;

Fehling's Factor $(\mathrm{g}$ of invert sugar $)=($ Titre $\times 2.5) / 1000$

\section{Preparation of sample}

$50 \mathrm{ml}$ of fruit juice was mixed with $100 \mathrm{ml}$ of distilled water and $5 \mathrm{ml}$ of neutral lead acetate solution and then kept for 10 minute and the mixture was homogenized. Then the blended material was transferred to a $250 \mathrm{ml}$ volumetric 
flask. The volume was made up to the mark with distilled water. Then solution was filtered.

\section{Titration of reducing sugar}

10milliliter of mixed Fehling's solution was taken in a $250 \mathrm{ml}$ conical flask and made $250 \mathrm{ml}$ with distilled water. Purifier juice solution (filtrate) was taken in a burette. Conical flask confining mixed Fehling's solution was heated on a hot plate. 3-5 drops of methylene blue indicator were added to the flask when boiling started and titrated against solution taken in burette. The end point was indicated by de-colorization of indicator. Percent reducing sugar was calculated according to the following formula;

$\%$ reducing sugar $=\frac{\mathrm{F} \times \mathrm{D} \times 100}{\mathrm{~T} \times \mathrm{W} \times 1000}$

Where, $\mathrm{F}=$ Fehling's factor, $\mathrm{D}=$ Dilution, $\mathrm{T}=$ Titer andW= Weight of sample.

Non-reducing sugar was estimated by using the following formula;

$\%$ Non-reducing sugar $=\%$ Total invert sugar $-\%$ Reducing sugar

$>$ Estimation of total sugar

$\%$ Total Sugar $=\%$ Reducing sugar $+\%$ Non- reducing sugar

\section{Measurement of total carotenoids:}

Total carotenoid was measured by taking 5 grams of the sample, grounded with acetone and anhydrous sodium sulphate in a pestle and mortar (Ranganna, 1986). Total carotenoids $(\mu \mathrm{g} / 100 \mathrm{~g})$ was measured by spectrophotometer (T-80, PG Instrument Ltd. UK) at $451 \eta \mathrm{m}$ (Alasalvaret al., 2005).

\section{Carbon-di-oxide measurement:}

The level of $\mathrm{CO}_{2}$ volume $\mathrm{ml} / \mathrm{g}$ fruit weight was measured by Archimedes' principle and expressed as $\mathrm{ml} / \mathrm{g}$ of fruits.

Residue level of ethephon:The residue level in treated mango was measured by Gas chromatography flame ionized detector in Toxicology laboratory, Entomology Division, BARI, Gazipur and SGS Laboratory, Dhaka and expressed as ppm (mg/kg). The method is stated by Rahman et. al. (2012).

Statistical analysis: Data analysis were performed by one-way ANOVA using software SPSS 20.0 (IBM INC: New York). Mean comparison was done by Tuky $\mathrm{w}$ test at $5 \%$ level of probability. All data were expressed in triplicate as means \pm standard deviation. 


\section{Results and Discussions}

Since there was no significant difference between two year's analytical data, pooled analysis was done and presented.

Effect on ripening: The investigation revealed that ethephon application enhanced the onset of ripening in mango and the response varied according to the concentrations ((Tables 1\&2). 100\% ripening was found when the fruits were treated with ethephon @10000ppm after 4 days of ambient storage. Almost all the fruits were fully ripened at 6 days of storage except control treatment. The ethephon (2-chloroethyl phosphonic acid) penetrates into fruit and decomposes to ethylene. Ethylene regulates the expression of several genes involved in fruits ripening so as to modulate the activity of various enzymes involved in the process of ripening (Beitz et al. 1977). These enzymes act to soften the skin of the fruit and also convert complex polysaccharides into simple sugars. It was explained by Holl (1977) in other way that the ethylene probably brings about the climacteric, since in many fruits the rise in respiration is directly preceded by an elevation in the ethylene concentration. This respiratory climacteric can be induced by ethylene treatment without a simultaneous change in tissue permeability. It has also been reported that ethylene alters the proportion of individual transfer RNA species.In support of the present study, the color development in mango fruits was remarkably affected by post-harvest application of ethephon. Out of all the concentrations, $1000 \mathrm{ppm}$ ethephon gave the most attractive and deep colored fruits. However, the specific mode of action of ethephon in accelerating color development is not clearly understood. Nour and Goukh (2010) observed that peel color score progressively increased during ripening of guava fruits. They observed that fruits treated with ethephon (250$1000 \mathrm{ppm}$ ) reached the full yellow stage 3, 4 and 6 days earlier than untreated fruits, respectively. They also reported ethephon treated fruits had reached the soft stage 2-6 days earlier than the control treatment.Color development was better due to rapid degradation of chlorophyll and higher synthesis of carotenoid pigmentation and alteration in pigment due to different applied ethephon treatment. These findings are more or less similar to the findings of Gurjar et. al (2017) and Sukhjit (2017) in mango.

Effect on weight loss: Table 2 indicates that the physiological loss in weight was significantly increased with the increase of applied ethephon concentrations. This might be due to rapid respiration and transpiration. The maximum weight loss $3.73 \%$ was observed at $\mathrm{T}_{6}(10000 \mathrm{ppm})$ where as it was only $1.74 \%$ in control treatment $\left(\mathrm{T}_{1}\right)$ at 6 days of ambient storage. Similar type of decrease in fruit weight during storage was also observed by Sharma and Singh (1981) in dates when dipped in 250-500 ppm ethephon for 5 minutes and by Gurjaret. al (2017) in 'Amrapali' when dipped into 250-1250 ppm ethephon. 
Effect on titratable acidity: It was observed from Table 2, that acidity of the mango fruit was not clearly understood by post-harvest application of ethephon and the response varied within the concentrations. Minimum titratable acid $(0.704 \%)$ was found in mango fruits treated with $1000 \mathrm{ppm}$ ethephon at 6 days of ambient storage. Similar finding was also noted in guava (Singh et al.,1979) and in date (Sharma and Singh, 1981). Riberau-Gayaon (1968) suggested that transformation of organic acids into sugars was one of the reasons for deceasing organic acids during fruit ripening. Therefore, another possibility seemed that ethephon might enhance the conversion of organic acids to sugars since present findings revealed that sugar content was increased and acidity was decreased following ethephon application.

Effect on total soluble solid (TSS): The maximum TSS $\left(20.7^{\circ} \mathrm{Brix}\right)$ was observed in $750 \mathrm{ppm}$ closely followed by $1000 \mathrm{ppm}\left(20.50^{\circ} \mathrm{Brix}\right)$ at 6 days of storage which was significantly different compared to control fruits $(12.8 \%)$ after 6 days of storage (Table 3). Similarly, increased total soluble solids due to post harvest application of ethephon was also reported by Singh et al. (1979) in guava, Sharma and Singh (1981) in date, Meitei et al. (1983) in peaches. The initial increased rate of TSS might be due to rapid loss of water from the fruits and the conversion of starch into sugar at a faster rate (Fernandez et al., 2006).

Effect on reducing sugar and total sugar: It revealed that the total sugars and reducing sugar increased with increasing ethephon concentration (Table $3)$. The maximum total sugar $(10.20 \%)$ and reducing sugar $(7.16 \%)$ was observed in treatment $T_{5}(1000 \mathrm{ppm})$ treated fruits at 6 days of ambient storage. The extent of sugar content increased up to 6 days of storage. Probably ethephon enhanced the rate of accumulation of reducing sugar in mango fruits. Similarly, high percentage of reducing sugar with ethephon application in dates was observed by Sharma and Singh (1981). The finding is corroborated with the result of Kumar and Singh (1993) who observed that higher percentage of sugar in ethephon $(750 \mathrm{ppm}$ and $500 \mathrm{ppm})$ treated mango fruits over control treatment.

Effect on ascorbic acid: The ascorbic acid decreased significantly up to 6 days after storage for all the treatment (Table 4). At 6 days of storage maximum ascorbic acid content was recorded in $1000 \mathrm{ppm}$ treated fruits $(29.12 \mathrm{mg} / 100 \mathrm{~g})$ followed by $750 \mathrm{ppm}$ treated fruits $(28.12 \mathrm{mg} / 100 \mathrm{~g})$. The fruits during storage, in general showed a declining trend in ascorbic acid content significantly irrespective of the treatments applied. A reduction in ascorbic acid content with the subsequent prolongation of storage might be due to rapid oxidation phenomenon of organic acid in later stage of storage (Orzolek and Argell, 1974). 
Effect on total carotenoid: A significant increase in total carotenoids was observed up to 6 days after storage in all the treatment (Table 4). The maximum total carotenoid was observed in 1000 ppm treated mango fruits (13.24 $\mu \mathrm{g} / 100 \mathrm{gm})$ at 6 days of ambient storage. Ethylene might increase the carotenoid content through its synthesis. This fact was established by Young and Jahn (1972) while working in citrus.

Effect on Carbon-di-oxide $\left(\mathrm{CO}_{2}\right)$ production: It was obvious from the experiment that $\mathrm{CO}_{2}$ level of the air-tight mango sample gradually increased with the increased ethephon application rate as well as with the storage period (Table 4). Maximum $\mathrm{CO}_{2}$ was found in $1000 \mathrm{ppm}$ treated fruits at 6 days of storage which was $8.60 \mathrm{ml} / \mathrm{g}$ fruits and the lowest was observed in control treatment $(5.17 \mathrm{ml} / \mathrm{g})$. It might be resulted from the increase in respiration rate of the fruit sample.

Residue analysis: The residue level was observed in all treated mangoes at 2, 4 and 6 days of storage (Table 5). Initially the maximum residue (ethephon) was observed in treatment $\mathrm{T}_{5}(1.86 \mathrm{ppm})$ followed by treatment $\mathrm{T}_{5}(1.80 \mathrm{ppm})$ and the minimum was found in treatment $\mathrm{T}_{2}(0.41 \mathrm{ppm})$ after 2 days of storage. It was observed that residue level decreased below themaximum residue level (MRL) of ethephon (2ppm). The residue level in treated fruits decreased with the increasing storage period and found the value was only $0.50-0.54 \mathrm{ppm}$ at 6 days of storage in case of 750 and $1000 \mathrm{ppm}$ ethephon treated fruits. The reason behind this is that it is very volatile compound and it completely agrees with Beitz et al., (1977).

Table 1. Effect of ethephon on color development during storage ofmango (cv. Langra)

\begin{tabular}{l|cccc}
\hline \multirow{2}{*}{$\begin{array}{c}\text { Treatments } \\
(\mathbf{p p m})\end{array}$} & \multicolumn{4}{c}{ Storage Days } \\
\cline { 2 - 5 } & 0 DAS & 2 DAS & 4 DAS & 6 DAS \\
\hline $\mathrm{T}_{1}=$ Control & Green & Green ,slight yellow & Green > yellow & Yellow > green \\
$\mathrm{T}_{2}=250 \mathrm{ppm}$ & Green & More green than yellow & Yellow $>$ green & Ripe \\
$\mathrm{T}_{3}=500 \mathrm{ppm}$ & Green & More yellow than green & Full ripe & Over-ripe \\
$\mathrm{T}_{4}=750 \mathrm{ppm}$ & Green & More yellow than green & Full ripe & Over-ripe \\
$\mathrm{T}_{5}=1000 \mathrm{ppm}$ & Green & Yellowish & Full ripe & Over-ripe \\
$\mathrm{T}_{6}=10000 \mathrm{ppm}$ & Green & Yellow & Over-ripe & Rotting \\
\hline
\end{tabular}

DAS=Days after storage 


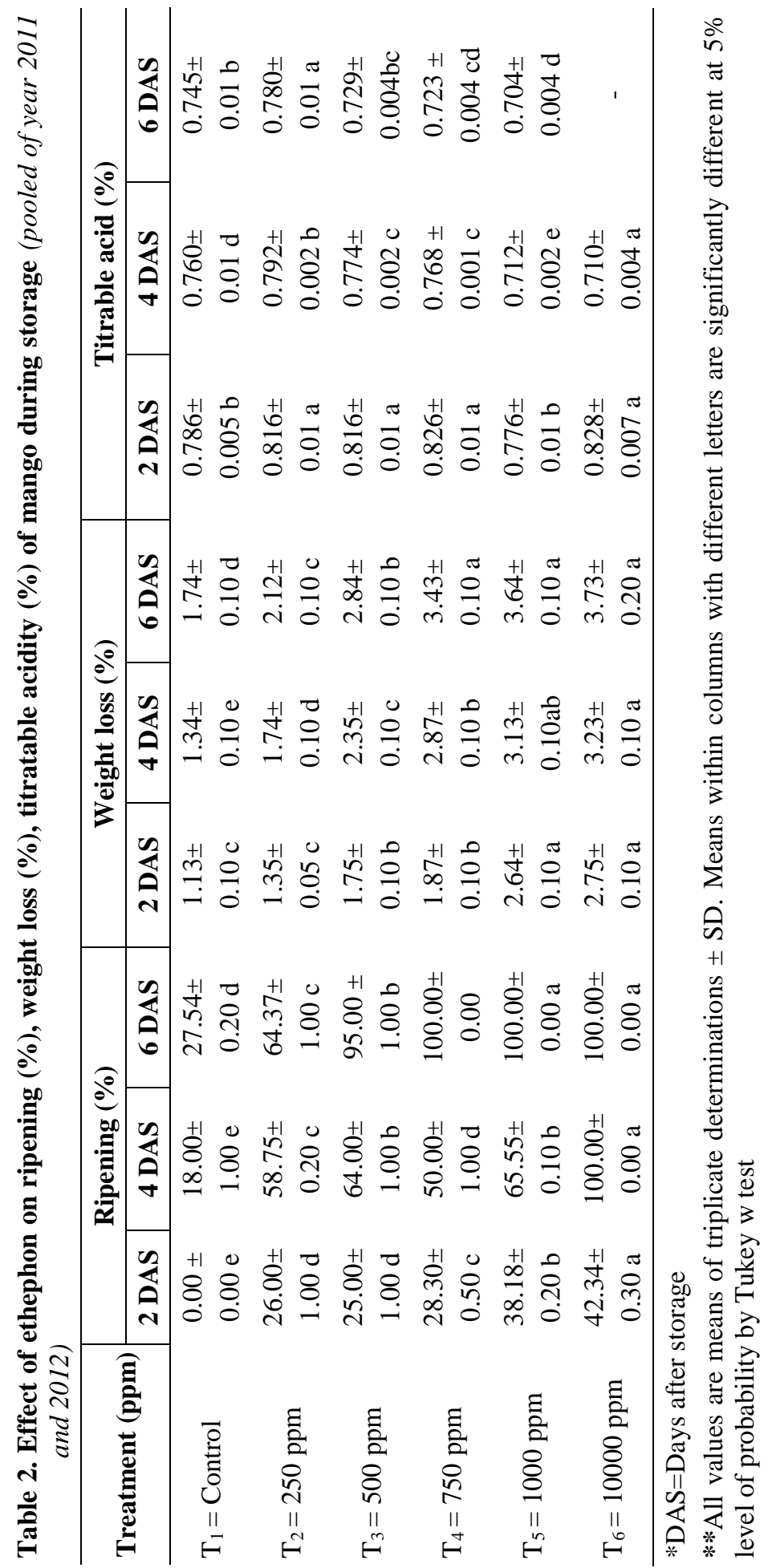




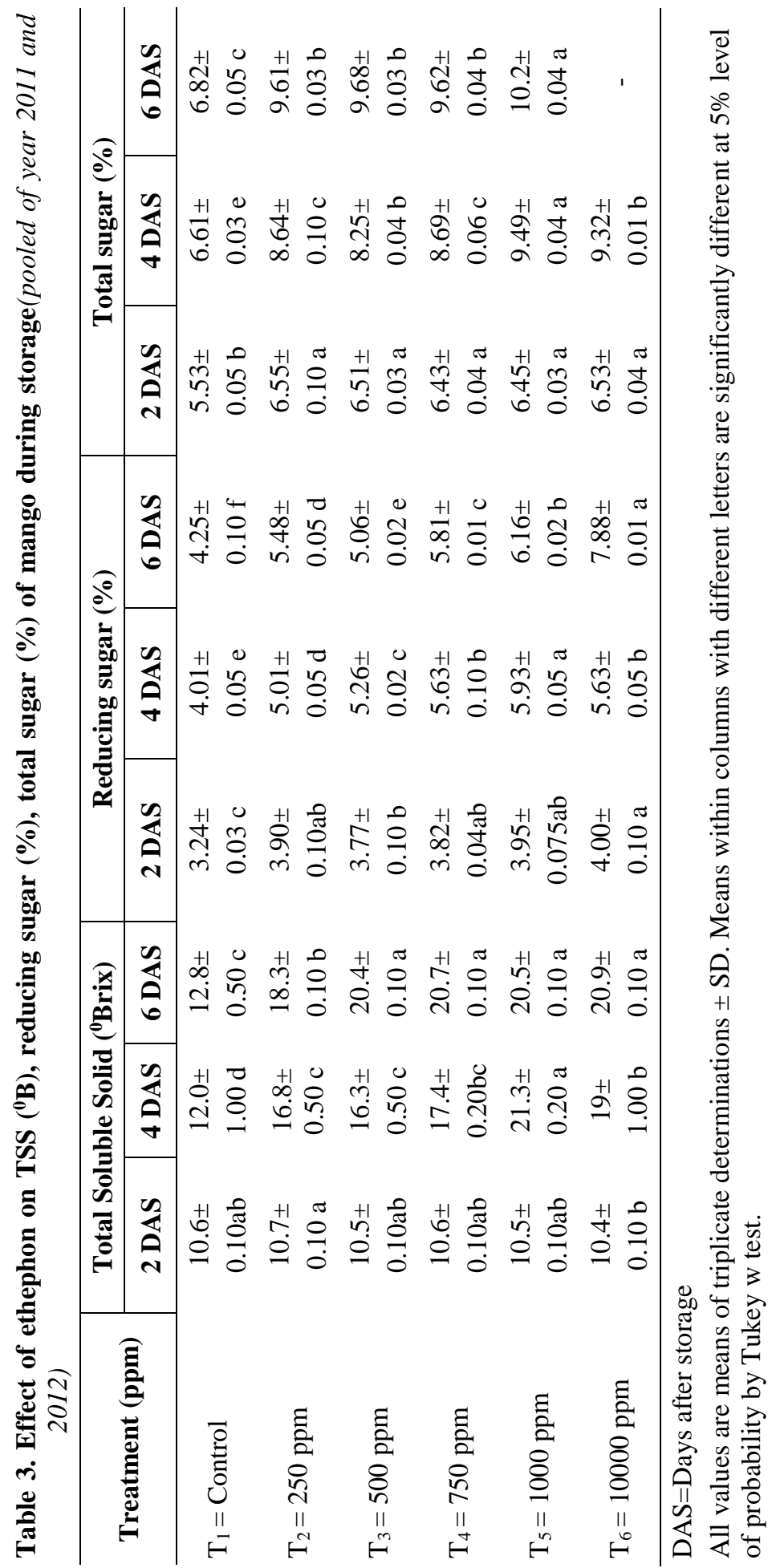




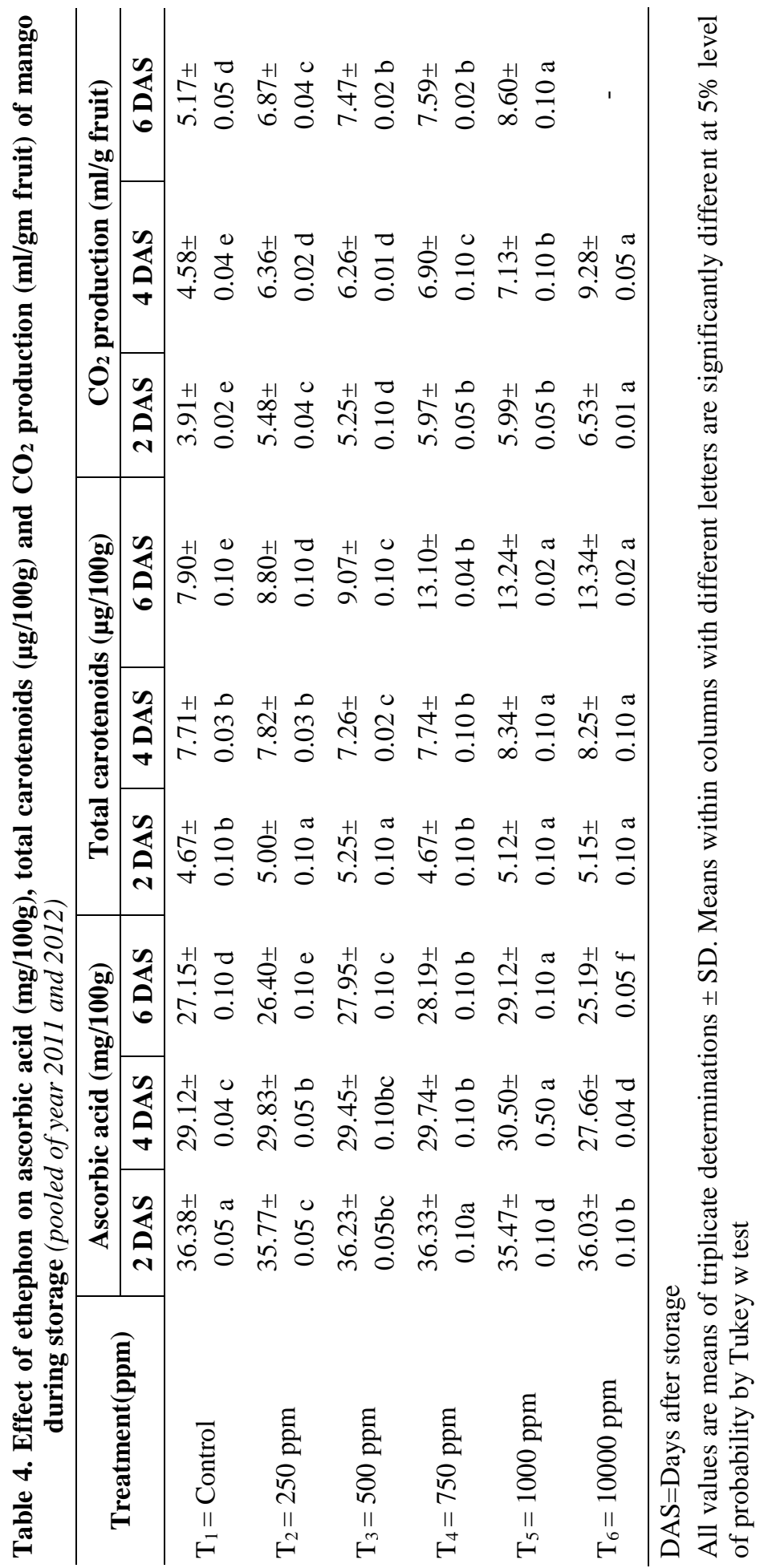


Table 5. Estimated residue level (ppm) of ethephon in treated mango (pooled of year 2011 and 2012)

\begin{tabular}{l|c|c|c}
\hline \multirow{2}{*}{ Treatments } & \multicolumn{3}{c}{ Days after storage } \\
\cline { 2 - 4 } & 2 DAS & 4 DAS & 6 DAS \\
\hline $\mathrm{T}_{1}=$ Control & $0.00 \pm 0.00 \mathrm{f}$ & $0.00 \pm 0.00 \mathrm{e}$ & $0.00 \pm 0.00 \mathrm{~d}$ \\
$\mathrm{~T}_{2}=250 \mathrm{ppm}$ & $0.41 \pm 0.03 \mathrm{e}$ & $0.26 \pm 0.02 \mathrm{~d}$ & $0.11 \pm 0.02 \mathrm{c}$ \\
$\mathrm{T}_{3}=500 \mathrm{ppm}$ & $0.64 \pm 0.02 \mathrm{~d}$ & $0.51 \pm 0.03 \mathrm{c}$ & $0.49 \pm 0.02 \mathrm{~b}$ \\
$\mathrm{~T}_{4}=750 \mathrm{ppm}$ & $0.85 \pm 0.02 \mathrm{c}$ & $0.53 \pm 0.02 \mathrm{c}$ & $0.50 \pm 0.01 \mathrm{ab}$ \\
$\mathrm{T}_{5}=1000 \mathrm{ppm}$ & $1.80 \pm 0.01 \mathrm{~b}$ & $1.28 \pm 0.02 \mathrm{~b}$ & $0.54 \pm 0.02 \mathrm{a}$ \\
$\mathrm{T}_{6}=10000 \mathrm{ppm}$ & $1.86 \pm 0.01 \mathrm{a}$ & $1.40 \pm 0.02 \mathrm{a}$ & - \\
\hline
\end{tabular}

DAS=Days after storage

All values are means of triplicate determinations \pm SD. Means within columns with different letters are significantly different at $5 \%$ level of probability by Tukey w test.

\section{Conclusion}

It can be concluded from the present investigation that the use of ethephon had a significant impact on the ripening and postharvest quality of mango fruits. Among the treatments ethephon application @ 1000 ppm was best for retaining the various physical and chemical parameters followed by ethephon application @ $750 \mathrm{ppm}$ till the 6 days of storage. Therefore, at matured green stage, ethephon can be applied@750-1000 ppm for uniform ripening of mango at ambient condition $\left(23 \pm 2^{\circ} \mathrm{C}\right)$ with $85 \pm 5 \%$ relative humidity. The estimated residue level in 750-1000 ppmethephon treated mango fruits at 4 and 6 days of storage remains lower than maximum residue limit (MRL) of ethephon (2ppm).

\section{References}

Alasalvar, C., M. Al-Farsi, P. Quantic, F. Shahidi and R.Wiktorowicz. 2005. Effect of chill storage and modified atmosphere packaging (MAP) on antioxidant, phenolics and sensory quality of ready-to-eat shredded orange and purple carrots. Food Chem. 89(1): 69-76. DOI: 10.1016/j.foodchem.2004.02.013.

Alexander, L. and D. Grierson. 2002. Ethylene biosynthesis and action in tomato: a model for climacteric fruit ripening. Journal of experimental botany.53 (377): 2039-2055.

Anonymous. 2001. European community position for the $33^{\text {rd }}$ session of the CODEX committee on pesticide residues. April, 2011. The Hague.

Anonymous. 2014. Illegal, Harmful. The Daily Star. September, 2014. www.thedailystar.net.

BBS. 2018. Yearbook of Agricultural Statistics of Bangladesh 2017. Planning Division, Ministry of planning, Government of the People's Republic of Bangladesh, Dhaka.

Beitz, H.,Banasiak, U., andU. Bergner.1977. Behavior of ethephon residue on tomatoes. Part 1. Green house tomatoes. 5 (4-6):131.

Bhandari, P., Meenakshi, Rajesh, P.K.Patanjali. 2017. Effect of Ethephon 39\% SL on postharvest applications on fruit ripening in mango. Journal of Natural Resource and 
Development.12(1):58-64. https :// www .cabdirect. org/ cab direct/ abstract 120173278435 .

Bui,Q.Q. 2007.Ethephon and jackfruit, Palo Alto, California.231pp.

Dhillion, W. S. and V.C. Mahajan. 2011. Ethylene and ethephon induced ripening in pear. J. Stored Products Postharvest Research. 2 (3): 45-51. http: // www . academic journanals.org/JSPPR.

Doke, N.D., J.K. Dhemre and V.K. Pad. 2018. Effect of ethrel on qualitative changes during ripening of mango (Mangifera indica L.) cv. Kaser. Int. J. Curr. Microbial. Appl. Sci.7 (2):1563-1571. http://ijcmas.com.

Fernandez, E. B., E. D. Etxeberria, F. J. Muñoz, M. Morán-Zorzano, N. AlonsoCasajús, P. Gonzalez, and J. Pozueta-Romero. 2006. An Important Pool of Sucrose Linked to Starch Biosynthesis is taken up by Endocytosis in Heterotrophic Cells. Plant Cell Physiol. 47(4): 447-456.

Gurjar, P.S., Verma, A.K. and D.K. Shukla. 2017. Effect of ethrel spray on the ripening behavior of mango (Mangifera indica L.) variety 'Dashehari'. J. Appl. Nat. Sci. 9 (3):1619-1623.

Hakim, M.A., A.K.O. Haq, M.A. Alam, A. Khatib, B. K. Saha, K.M.F. Haque, and I.S.M. Zahidul. 2012. Role of health hazardous ethephone in nutritive values of selected pineapple, banana and tomato. Journal of Food Agriculture and Environment. 10(2):247-251.

Holl, W. 1977. Fruit ripening. Plant Res. Dev.5:117-126.

Kumar, P. and S. Singh. 1993. Effect of $\mathrm{GA}_{3}$ and etherl on ripening and quality of mango cv. Amrapali. The Hort. J.6(1): 19-23.

Lane, J.H. and L. Eynon. 1923. Determination of reducing sugars by means of Fehling's solution with methylene blue as internal indicator. J. Soc. Chem. Ind. Trans.42:32-36.

Mahajan, B.V.C., G. Singh and A.S. Dhatt. 2008. Studies on ripening behavior and quality of winter guava with ethylene gas treatments. J. Food. Sci. Technology.47 (3):315-319. DOI: 10.100/s13197-010-0050-0.

Mahajan, B.V.C., C. K. Tajender, M. S. L. Gill, H.S. Dhaliwal, B.S. Ghuman and B.S. Chahlil. 2010. Studies on ripening techniques for banana. J. Food. Sci. Technology.4:81-84.

Meitei, S. B., R. K. Patel, D. C. Bidyut, N. A. Deshmukh and A. Singh. 1983.Effect of chemical thinning on yield and quality of peach cv. Flordasun. African Journal of Agricultural Research. 8 (27): 3558-3565.

Moniruzzaman, M., R. Khatoon, , M.F.B. Hossain, M.T. Rahman and S. N Alam. 2015. Influence of ethephon on ripening and quality of winter tomato fruit harvested at different maturity stages.Bangladesh Journal of Agricultural Research. 40(4): 567-580.

Nour, I. A. M. and A. B. A. Abu-Goukh. 2010. Effect of ethrel in aqueous solution and ethylene released from ethrel on guava fruit ripening. Agriculture and Biology Journal of North America. 1(3): 232-237.

Orzolek, M.D. and F.F. Argell. 1974. Effect of ethephon on ascorbic acid and soluble solids in processing tomato cultivars. Hort. Sci.9:306. 
Rahman, M.A., M.S. Ahmed, A. Begum and M. W. Akon. 2012. Determination and quantification of left over residues of ethephon in tomato, banana and mango. Annual report for 2011-2012. Entomology Division, Bangladesh Agricultural Research Institute, Gazipur. pp. 192-197.

Ranganna, S.1986. Handbook of analysis and quality control for fruits and vegetables. Tata Mc. Graw Hill Publishing Company Limited. New Delhi-110.

Ribereau-Gayon, G. 1968. Etudedes mechanisms synthese at de transformation delacidemailique, de l' acid etartique at de I'acid emailique, chaz Vitis vinifera L. Phytochem. 7:1471-1482.

Sharma, R.K. and I.S. Singh. 1981, Effect of preharvestapplication of ethylene on ripening and quality of two cultivars of date. First National Work shop on Arid Zone Fruit Research held at H.A.U., Hissar.

Singh, H.K., I.S. Singh, and K.S. Chauhan.1979. Effect of pre-harvest application of ethylene on ripening and quality of guava cv. Sardar .Udyanika. 2:117-120.

Sukhjit, K. 2017. Effect of different treatments of ethrel on ripening behavior and postharvest quality of mango (Mangifera indica L.) during storage. J. Appl. Nat. Sci. 9 (1):85-93. www.jans.ansfoundation.org.

Young, R. and O. Jahn. 1972. Ethylene induced carotenoids accumulation in citrus rind. J. Amer. Soc. Hor. Sci.97:258-261.

Zhu, H. L., B. Z. Zhu, D.Q. Fu, Y. H. Xie, Y. L. Hao and Y. B. Luo. 2005. Role of ethylene in the biosynthetic pathways of aroma volatiles in ripening fruit. Russian Journal of Plant Physiology.52 (5):691-695. 
